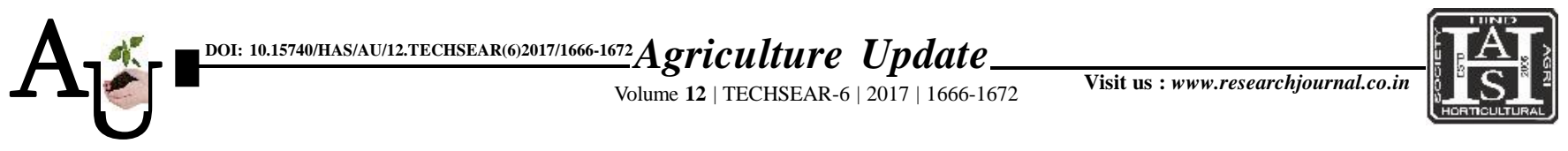

\title{
Research Article: Seasonal incidence of shorthorned grasshoppers in agriculture and forest ecosystem of Dharwad region
}

\author{
B. RAGHAVENDER, A.S. VASTRAD, V. RATNAKAR, V. SUNIL AND \\ B. THIRUPAM REDDY
}

Article Chronicle : Received : 17.07.2017;

Accepted :

01.08 .2017

KEY Words :

Shorthorned

grasshopper,

Agriculture, Forest

ecosystem

Author for correspondence :

\section{B. RAGHAVENDER}

Department of

Agricultural

Entomology, University

of Agricultural Sciences,

DHARWAD (KARNATAKA)

INDIA

Email: raghu3758

@ gmail.com
SUMMARY : Seasonal incidence of grasshopper revealed that population build up was started after the onset of monsoon showers and the adults were abundant during post monsoon period (JulyNovember). In Dharwad, grasshopper population was minimum during April and maximum during September. In Prabhunagar (Forest ecosystem), grasshopper population was minimum during May and maximum during September. Diversity study during different seasons showed rainy season was more diverse followed by winter and summer season.

How to cite this article : Raghavender, B., Vastrad, A.S., Ratnakar, V., Sunil, V. and Reddy, B. Thirupam (2017). Seasonal incidence of shorthorned grasshoppers in agriculture and forest ecosystem of Dharwad region. Agric. Update, 12(TECHSEAR-6) : 1666-1672; DOI: 10.15740/HAS/AU/12. TECHSEAR(6)2017/1666-1672. 